\title{
Task 2.3 - Review and Assessment of Results From the Comprehensive Characterization of Toxic Emissions From Coal-Fired Power Plants
}

\author{
Semi-Annual Report \\ January 1 - June 30, 1997 \\ By: \\ Sumitra R. Ness
}

Work Performed Under Contract No.: DE-FC21-93MC30097

For

U.S. Department of Energy

Office of Fossil Energy

Federal Energy Technology Center

P.O. Box 880

Morgantown, West Virginia 26507-0880

By

Energy \& Environmental Research Center

University of North Dakota

P. O. Box 9018

Grand Forks, North Dakota 58202-9018 


\section{DISCLAIMER}

Portions of this document may be illegible in electronic image products. Images are produced from the best available original document. 


\section{DISCLAIMER}

This report was prepared as an account of work sponsored by an agency of the United States Government. Neither the United States Government, nor any agency thereof, nor any of their employees makes any warranty, express or implied, or assumes any legal liability or responsibility for the accuracy, completeness, or usefulness of any information, apparatus, product, or process disclosed or represents that its use would not infringe privately owned rights. Reference herein to any specific commercial product, process, or service by trade name, trademark, manufacturer, or otherwise does not necessarily constitute or imply its endorsement, recommendation, or favoring by the United States Government or any agency thereof. The views and opinions of authors expressed herein do not necessarily state or reflect those of the United States Government or any agency thereof.

\section{ACKNOWLEDGMENT}

This semiannual was prepared with the support of the U.S. Department of Energy (DOE), Federal Energy Technology Center, Cooperative Agreement No. DE-FC21-93MC30097. However, any opinions, findings, conclusions, or recommendations expressed herein are those of the author(s) and do not necessarily reflect the views of the DOE.

\section{EERC DISCLAIMER}

LEGAL NOTICE This research report was prepared by the Energy \& Environmental Research Center (EERC), an agency of the University of North Dakota, as an account of work sponsored by the U.S. Department of Energy. Because of the research nature of the work performed, neither the EERC nor any of its employees makes any warranty, express or implied, or assumes any legal liability or responsibility for the accuracy, completeness, or usefulness of any information, apparatus, product, or process disclosed, or represents that its use would not infringe privately owned rights. Reference herein to any specific commercial product, process, or service by trade name, trademark, manufacturer, or otherwise does not necessarily constitute or imply its endorsement or recommendation by the EERC. 
TABLE OF CONTENTS

1.0 INTRODUCTION 1

2.0 OBJECTIVES

.1

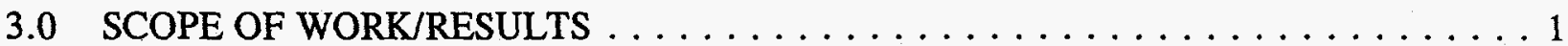

Subtask 1 - Initial Review of Nine Draft Field Reports $\ldots \ldots \ldots \ldots \ldots \ldots \ldots$

Subtask 2 - Recommendations for Phase II Field Tests $\ldots \ldots \ldots \ldots \ldots \ldots \ldots$

Subtask 3 - Summary Report of Phase I Tests . . . . . . . . . . . . . 2

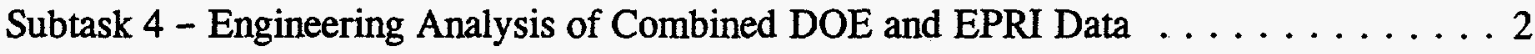

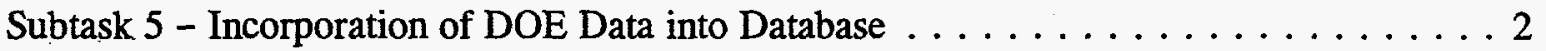

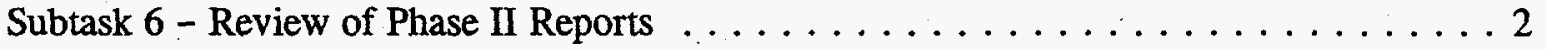

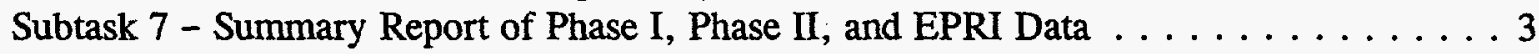

4.0 FUTURE WORK

3

5.0 REFERENCES

3

i 


\section{TASK 2.3 - REVIEW AND ASSESSMENT OF RESULTS FROM THE COMPREHENSIVE CHARACTERIZATION OF AIR TOXIC EMISSIONS FROM COAL-FIRED POWER PLANTS}

\subsection{INTRODUCTION}

To help meet the requirements of the 1990 Clean Air Act Amendments, the U.S. Department of Energy (DOE) sponsored Phase I of a study entitled "Comprehensive Characterization of Toxic Emissions from Coal-Fired Power Plants" in 1992. Final reports which detail air toxic emissions from eight power plants (nine configurations) were completed by the contractors. The Energy \& Environmental Research Center (EERC) served as an independent third-party reviewer of these reports; it has completed the activities as outlined for the initial review process and has prepared two reports. The first report, entitled "A Comprehensive Assessment of Toxic Emissions from Coal-Fired Power Plants: Phase I Results from the U.S. Department of Energy Study" was published in September 1996 and is available to the public and private sectors through the U.S. Department of Energy (DOE) Federal Energy Technology Center (FETC) at Pittsburgh. This report summarizes and evaluates the stack emission data. The second report prepared by the EERC, entitled "A Comprehensive Assessment of Toxic Emission from Coal-Fired Power Plants:

Statistical Correlations from the Combined DOE and EPRI Field Test Data," details empirical correlations derived from the Phase I DOE data and the Electric Power Research Institute (EPRI) PISCES (Power Plant Integrated Systems: Chemical Emissions Studies) data.

\subsection{OBJECTIVES}

The objective of the project was to provide an independent review of the Phase I data, evaluate the scientific validity of the conclusions, identify significant correlations between emissions and fuel or process parameters, compare the data with available data from EPRI studies, make recommendations for future studies, and complete a combined report that summarizes Phase I, Phase II, and EPRI findings.

\subsection{SCOPE OF WORK/RESULTS}

The work was divided into seven tasks beginning with the initial review of nine draft reports from Phase I through the completion of a final summary report targeted to include Phase I, Phase II, and EPRI results.

\section{Subtask 1 - Initial Review of Nine Draft Field Reports}

The EERC review team compiled comments for each of the nine draft field reports to serve as a guide for the individual contractors to prepare their final reports. Conference calls were held between the EERC, DOE, and the respective contractors for each of these reports. Final reports for each field site were completed in 1994. 


\section{Subtask 2 - Recommendations for Phase II Field Tests}

Based on the review of the Phase I reports and past EERC experience, a report entitled "Task 2 - Recommendations for Phase II Field Tests" 95-EERC-01-03, was delivered in April 1995 to DOE, which included suggested reporting format changes, a pre-field-sampling laboratory preparation and qualification exercise, a data-reporting and flagging system, quantity and types of required samples, changes in inorganic and organic sampling and analytical procedures, and quality assurance/quality control (QA/QC) target objectives.

\section{Subtask 3 - Summary Report of Phase I Tests}

The summary report of the Phase I tests was completed and published by the EERC (1) in September 1996 and is available to the public and private sectors through DOE FETC at Pittsburgh. Information presented in the summary report includes the round-robin coal analyses and the individual site coal data; the emission factors for inorganic, organic, radionuclide, and acid gas-halogen species; the effects of coal characteristics and process configurations on emission factors; and several special topics, including plume simulation dilution sampling, the distribution of hazardous air pollutants (HAPs) as a function of particle size, chromium sampling and speciation, the effect of sootblowing on metals emissions, and others.

\section{Subtask 4 - Engineering Analysis of Combined DOE and EPRI Data}

The objectives of Subtask 4 were to compare the trace element emissions data from Phase I with the trace element emissions data that are available from EPRI-sponsored field tests to identify potential relationships between stack emissions of trace element species and coal, operating, and process parameters.

A Microsoft ${ }^{\circledR}$ Access database of DOE and EPRI data was completed and used to develop empirical models describing the emission for trace element species derived from the statistical evaluation of likely variables in the database. The number of variables used in the empirical models were systematically reduced using the multiple linear regression procedure (REG) from the SAS ${ }^{\text {TM }}$ statistical software package. A written draft of this correlation report was submitted, and highlights were presented to DOE in July 1995.

\section{Subtask 5 - Incorporation of DOE Data into Database}

The Phase I data were entered into the Center for Air Toxic Metals (CATM) database, which is now available to CATM sponsors, including DOE.

\section{Subtask 6 - Review of Phase II Reports}

No Phase II reports have been reviewed to date because of a delay in the DOE sampling efforts. In lieu of Phase II reports, the Paradise Plant and Blacksville Plant reports written by Southern Research Institute were reviewed, as well as Battelle's QA/QC plan and final report for pilot-scale sampling performed at DOE and its Sammis Plant report. 


\section{Subtask 7 - Summary Report of Phase I, Phase II, and EPRI Data}

Because Phase I sampling efforts have been delayed, a summary report of Phase I, Phase II, and EPRI data will not be written under this project.

\subsection{FUTURE WORK}

The objectives of this project were met by the EERC with the available data, and additional reports were reviewed by the EERC in lieu of the data not available. The EERC has submitted a $\$ 250,000$ proposal to DOE FETC for continued work in the area of air toxics review with the following objectives:

- Finalize and publish the existing Phase I statistical correlations report, and prepare a Phase II statistical correlations report integrating Phase I data with Phase II data.

- Compare toxic emission data from the Sammis Plant (full-scale) with data from the DOE FETC at Pittsburgh 500-lb/hr plant (pilot-scale) data to determine whether the pilot-scale data are representative of the full-scale data.

- Update and publish the existing Phase I recommendations report for the benefit of air toxic sampling and analytical teams in both the public and private sectors.

- Prepare journal articles from the Phase I site reports and summary report to make these valuable data easily accessible to the public and the scientific communities.

- Ensure the highest possible data quality in Phase II by providing review of QA/QC sampling and analytical plans prior to field sampling and on-site auditing during field sampling.

- Perform both a technical and general review of the data reduction and sample analyses in the Phase II draft reports to ensure that the data are documented and presented in a standard format that is easily interpreted by other users.

- Prepare a combined Phase I and II final summary report to be used as a basis for further HAP research and regulation.

\subsection{REFERENCES}

1. Miller, S.J.; Ness, S.R.; Weber, G.F.; Erickson, T.A.; Hassett, D.J.; Hawthorne, S.B.; Katrinak, K.A.; Louie, P.K.K. "A Comprehensive Assessment of Toxic Emissions from CoalFired Power Plants: Phase I Results from the U.S. Department of Energy Study," final report for U.S. DOE DE-FC21-93MC30097; EERC publication, Sept. 1996. 